\title{
Ongoing quiescence in the Borborema Plateau Plague focus (Paraiba, Brazil)
}

\author{
CAIO G. ZEPPELINI ${ }^{1}$, ALZIRA M.P. DE ALMEIDA ${ }^{2}$ and PEDRO CORDEIRO-ESTRELA ${ }^{1}$
}

\author{
${ }^{1}$ Programa de Pós-Graduação em Ciências Biológicas, Centro de Ciências Exatas e da Natureza, Universidade \\ Federal da Paraíba, Cidade Universitária, s/n, Castelo Branco, 58051-900 João Pessoa, PB, Brazil \\ ${ }^{2}$ Centro de Pesquisa Aggeu Magalhães / Fiocruz, Campus da Universidade Federal de Pernambuco, \\ Av. Professor Moraes Rego, s/n, Cidade Universitária, 50740-465 Recife, PE, Brazil
}

Manuscript received on December 5, 2017; accepted for publication on April 4, 2018

\begin{abstract}
Plague is a zoonosis caused by Yersinia pestis, whose cycle is based on a reservoir system composed of mammals and their fleas. Its transmission cycle presents long enzootic periods with undetected cases, sometimes misleading that the cycle is extinct. While surveillance activities in Brazil are being carried out only in some focal areas, the serologic results confirm the persistence of $Y$. pestis in all monitored areas. We studied the small mammal assembly and Y. pestis presence in the Borborema Plateau Focus within the state of Paraíba, which staged the last Brazilian plague outbreak (1986-1987), through an inventory and $Y$. pestis detection survey of small mammals in peridomestic and sylvatic areas from two municipalities in the state of Paraíba. The field sampling captured 45 specimens (27 marsupials, 18 rodents), of 10 species. Only two species (one marsupial, one rodent) were captured in both peridomestic and sylvatic ecotopes. The sylvatic ecotope had higher richness and abundance. No evidence of circulation of the pathogen was detected, however, this result does not discard the necessity of continuous epidemiological surveillance due to the risk of rekindling the foci after long dormant periods, especially given the current epidemiological transition occurring on a Global scale.
\end{abstract}

Key words: small mammals, peridomestic environment, Yersinia pestis, quiescence, surveillance.

\section{INTRODUCTION}

Plague is a zoonosis caused by Yersinia pestis, a gram-negative bacteria from the family Enterobacteriaceae, transmitted primarily by the bite of fleas infected by feeding on small mammals that compose Plague's reservoir system (Perry and Fetherston 1997). Humans are incidental hosts, hence the high mortality rate of the infection, and

Correspondence to: Caio Graco Zeppelini

E-mail: czeppelini@gmail.com human plague cases usually occur during epizootics (Perry and Fetherston 1997).

The transmission cycle of plague presents long enzootic periods, where its activity is undetected (Haule et al. 2013), sometimes giving the misleading impression that the cycle is extinct. However, long dormant foci can reemerge (Stenseth et al. 2008), as it has been recently reported in African foci (Malek et al. 2014), a region that concentrates $90 \%$ of the current cases (Raoult et al. 2013), and where several 
countries and regions that do not present recent activity might potentially rekindle (Lotfy 2015).

Plague is still a global Public Health concern (Stenseth et al. 2008, Butler 2013), and current foci are spread throughout the Americas, Africa (mainly in Sub-Saharan), Eastern Europe and Asia, with some foci returning to activity and others presenting noticeable changes in behavior (Gage and Kosoy 2005, Holt et al. 2009, Zeppelini et al. 2016). The World Health Organization (WHO) considers pneumonic plague a PHEIC (Public Health Emergency of International Concern), and states in the International Health Regulations that cases must be immediately reported (WHO 2005).

Plague entered Brazil through the port of Santos in 1899, with rapid expansion to other port cities (Politzer and Meyer 1965). The spread in the countryside happened through the terrestrial commerce routes and railways; finally establishing several foci in the native small mammal assemblages in Brazil. More specifically, in the mid altitude $(>500 \mathrm{~m})$ semi-arid regions of the Northeast states, and northern Minas Gerais (Tavares et al. 2012), and in the Serra dos Orgãos in the state of Rio de Janeiro (Ministério da Saúde 2008).

As an infectious disease with high mortality and morbidity, it is imperative to maintain constant surveillance of the foci since the cycle can undergo quiescence periods where the infection lies undetectable (Haule et al. 2013). In Brazil, the plague surveillance program was firstly based on rodent trapping and collection of fleas for bacterial detection, serosurveys on rodent domestic carnivores (dogs and cats) populations (Almeida et al. 1981, 1987, 1995). Since 2007, the surveillance was restricted solely to serosurveys in domestic carnivores as sentinels of infection (Tavares et al. 2012). While surveillance activities are being carried out only in some focal areas, the results confirm the presence of $Y$. pestis in the monitored areas.
Only in the latter half of this decade was fieldwork conducted with a focus on trapping and examining the circulation of the pathogen among the small mammal assemblages of the foci, including marsupials. These studies also examined the current state of the foci under effects of anthropogenic impacts and climate change, and performed a taxonomical update of the reservoir species (Costa et al. 2017, Bonvicino et al. 2015). Nonetheless, the studies did not sample the Borborema Plateau Focus, especially its portion in the state of Paraíba where the last Brazilian plague outbreak was reported (1986-1987) (Almeida et al. 1989).

The present study summarized the results of the first recent inventory and $Y$. pestis detection survey performed in the historical plague area in the Paraíba state. This area was chosen based on the lack of surveillance efforts for the last 20+ years, contrasting with both the WHO recommendations and the surveillance efforts maintained continuously in other foci. Also, this region had one of the last outbreaks recorded in Latin America (Schneider et al. 2014), but was not sampled in the most recent studies (Costa et al. 2017). The sampling design was chosen in order to address the historical bias of surveillance efforts, which have not previously covered sylvatic areas, and only concentrated on rapid risk assessment for epidemiological reasons (Tavares et al. 2012); allowing for observation of the faunal composition differences between the two environments and their possible implications on the transmission cycle and infection profiles.

\section{MATERIALS AND METHODS}

\section{STUDY AREA}

The Borborema Plateau is a geographic formation that extends in NE-SW orientation, with altitudes up to $1200 \mathrm{~m}$ (500 m of avg. altitude) (Morais Neto et al. 2009). The Plateau is divided into three sections: East Slope, West Slope and Central Plateau, and is 
surrounded by the Depressão Sertaneja in the West, the Coastal Plain in the East, and the Sertanejo Plateau in the Southeast (Ministério das Minas e Energia 1981). The Köppen climatic classification of the Plateau is divided grossly in Cwa, Cwb (tropical/subtropical humid) and BSh (semi-arid) (Alvares et al. 2013).

To define the spatial limits of the Borborema Plateau focus, the shapefile for Brazilian topographic formations, available for download at the Ministry of Environment website (http:// mapas.mma.gov.br/i3geo/datadownload.htm), was used. Topographic information was used for delimitation due to the lack of a resource that sets the geographical borders of the plague foci, and the literature does not provide a clear delimitation on its maps (Vieira et al. 1994).

\section{SITE SELECTION}

To select the sites to be surveyed, historical information of municipalities and locations where the surveillance teams conducted investigation on rodents, their fleas, sentinel animals and notified human cases during the 1986/87 outbreak was recovered (Almeida et al. 1989). Fieldwork files $(n=324)$ available at the National Reference Service on Plague (Fiocruz PE), registering the animal surveys, and the registry of 412 human patients from 208 localities distributed in 45 municipalities were consulted. Out of the 45, the municipalities Areia and Alagoa Grande were selected due to accessibility, support infrastructure, and permission to perform peridomestic sampling from the property owners.

\section{STUDY DESIGN}

Two different ecotopes, peridomestic and sylvatic areas, were explored. Peridomestic areas were defined as the areas that encompass direct human activities, including housing, functional buildings (barns, garages, storage areas), pasture and crop areas. Sylvatic areas were considered remnants of original vegetation from the Caatinga dry forestscrubland biome that were large enough for the installation of the trapping trails.

Each municipality was surveyed for 13 days, divided into two phases. The first included 6 days of trapping, with 160 traps total (80 for peridomestic, 80 for sylvatic), and the second had 7 days of trapping, employing 120 traps (60 for peridomestic, 60 for sylvatic). The traps were installed in trails with 20 traps with 10 meter intervals between traps, and each trail 500 meters apart of each other, to guarantee independence between trails. Peridomestic and sylvatic areas surveyed were also at least 500 meters from each other. Equal numbers of Sherman ${ }^{\circledR}(7.64 \times 9.53$ x $30.48 \mathrm{~cm})$, Tomahawk ${ }^{\circledR}(40.64$ x 12.7 x 12.7 $\mathrm{cm}$ ) and PCP model live traps were employed. The sampling design and other research procedures were approved by the Ethics Committee on Animal Use for Research of UFPB (license \#121/2016), and under SISBIO license \#8164-1.

The traps were baited with a mix of bananas, oatmeal, paçoca (grounded peanuts sweets) and canned sardines in oil. The trails were visited daily in the early morning to replace traps that had captured animals. Baits were replaced daily.

\section{SAMPLE COLLECTION AND PROCESSING}

Captured small mammals were brought to a field processing site, where they were handled after physical and chemical contention with a mixture of nine parts of Ketamine (10\% solution) and one part Acepromazine ( $2 \%$ solution) for rodents; and a mixture of one part Ketamine (10\% solution), one part Xylazine ( $1 \%$ solution) for marsupials, using a dosage of $0.1 \mathrm{ml}$ for each $50 \mathrm{~g}$ of body weight. Sedation was confirmed by absence of ocular and limb reflexes. Blood samples were collected by cardiac puncture using a $20 \times 0.55 \mathrm{~mm}$ needle on a $3 \mathrm{ml}$ syringe, followed by centrifugation at 5000 
RPM for five minutes, with separation of serum and cells in different Eppendorf $₫$ containers sealed with Parafilm ${ }^{\circledR}$ and frozen at $-10^{\circ} \mathrm{C}$.

After death, the peritoneal cavity was accessed via abdominal incision, from which the spleen was extracted and stored in Cary-Blair transport medium (Zhejiang Gongdong Medical Technology CO. LTD, Taizho, 318020, China). Liver and skin samples were obtained for deposit in a genetic repository, along with the taxidermied individuals, at Collection of Mammals of Universidade Federal da Paraíba, Campus I.

\section{LABORATORY ANALYSIS}

Hemagglutination assays (HA) with hemagglutination Inhibition control (HI) was performed to detect specific antibodies for the $Y$. pestis capsular protein Fraction 1 or F1 (Chu 2000).

Spleen samples in Cary-Blair medium were triturated and plated directly on a Blood Agar Base medium (HiMedia Laboratories Pvt Ltd 23, Vadhani Industrial Estate, LBS Marg, Ghatkopar West, Mumbai, Maharashtra 400086, India) for identification and isolation of $Y$. pestis. The plates were incubated at $28{ }^{\circ} \mathrm{C}$ for 48 to 72 hours and checked daily to observe the colony growth and the lysis of the colonies by the anti-plague bacteriophage (Karimi 1978).

For molecular analysis, fractions of the spleen triturates were partially purified to eliminate inhibitors of the PCR reaction, the product suspended in Tris-EDTA and analyzed by multiplexPCR (M-PCR), targeting the amplification of plasmidial (pla, lcrV, cafl) and chromosomic (irp2) genes, the prominent virulence markers for Y. pestis (Leal and Almeida 1999). Purified DNA of Y. pestis CYP 0803 (isolated from a patient at Sítio Carnaúba, in São Benedito - Ceará, 1978 from the CYP Fiocruz collection) was used as positive control, and a tube with all reagents (but no DNA samples) as negative control. The molecular weight marker was the $100 \mathrm{bp}$ DNA ladder (Invitrogen).

\section{RESULTS}

\section{FIELDWORK}

In Alagoa Grande, field work was conducted at Fazenda Riachão do Progresso (FRP) (0706'01', $\mathrm{S} ; 35^{\circ} 35^{\prime} 57^{\prime \prime} \mathrm{W}$ ), a rural estate with cattle raising (bovines and goats) as the main economic activity, and with maize crops planted in smaller lots inside the FRP's limits. The peridomestic trails were set alongside the main infrastructure, where the main house is located and where vehicles, equipment and other materials are stored; along pasture areas and across corn fields. The sylvatic trails were installed in fragments of shrub-arboreal Caatinga, which comprises a dry forest with low canopy (about $3 \mathrm{~m}$ ), vestigial or absent litter and abundance of rock fragments in soil; following pre-existent trails and opening new paths. The fragments surveyed were on low hills, and one of the fragments was partially surrounding a communitarian artificial lake that is utilized for fishing, water supply and recreation.

In Areia, fieldwork was conducted at Engenho Bujari, a sugarcane mill that produces sugar and rapadura. The property's legal native vegetation reserve, composed by a large fragment of Brejo de Altitude, enclaves of montane semi-deciduous seasonal forest, occurs windward on the Notheast plateaus within the Caatinga and has an altitude of 100 to 600 meters (Rodal et al. 2005). The occurrence of orographic precipitation, fed by the humid winds that blow east-west coming from the Atlantic Ocean, are responsible for high precipitation $(>1200 \mathrm{~mm} / \mathrm{y})$ and the Atlantic Forest-like characteristics of the Brejos (Pôrto et al. 2004). The legal reserve, located at the highest point of the property, at the level of the State road, was surveyed as the sylvatic ecotope, following pre-existent lumbering trails that present signs of deactivation for several years (i.e. vegetation 
growing in the trails). The peridomestic trails were installed in the sugarcane fields, with the exception of one set of 20 traps that were not arranged on a trail but rather installed in the buildings where sugarcane and rapadura are stored and processed.

\section{SAMPLING RESULTS}

The sampling performed in field summed up to 3640 traps/night, capturing 45 specimens of ten species.

Eighteen rodent specimens distributed in ten species were trapped during the study (Table I). The only invasive species (Rattus rattus) was the most abundant, and was captured only in peridomestic areas. The peridomestic ecotope had the biggest number of captured animals, mainly due to Rattus rattus numbers. Twenty-seven marsupials from four species were trapped (Table I). Didelphis albiventris was the most abundant marsupial species, although ten individuals were juveniles and released on site.
The sylvatic ecotope had more species and individuals captured than the peridomestic. Only one rodent species (Galea spixii), and one marsupial (Monodelphis domestica), were captured in both ecotopes.

\section{LABORATORY ANALYSIS}

Twenty-seven spleen samples collected from marsupials (12) and rodents (15) were analyzed by culture and M-PCR yielding negative results for $Y$. pestis. Seven serological samples from marsupials (3) and rodents (4) were also negative for antiplague antibodies.

\section{DISCUSSION}

This study is one of very few that assess the role of two potential participants of the transmission cycle that are often underestimated: non-rodent small mammals and the sylvatic, non synanthropic small mammal assemblages. In South America, there

TABLE I

Specimens captured during the field survey, discriminated by locality and ecotope.

\begin{tabular}{|c|c|c|c|c|}
\hline & \multicolumn{2}{|c|}{ Alagoa Grande } & \multicolumn{2}{|c|}{ Areia } \\
\hline & Sylvatic & Peridomestic & Sylvatic & Peridomestic \\
\hline \multicolumn{5}{|l|}{ Order Didelphimorphia } \\
\hline Didelphis albiventris & & & 12 & \\
\hline Gracilinanus agilis & 4 & & & \\
\hline Marmosa demerarae & & & 4 & \\
\hline Monodelphis domestica & 3 & 4 & & \\
\hline \multicolumn{5}{|l|}{ Rodentia:Cricetidae } \\
\hline Rhipidomys mastacalis & & & 1 & \\
\hline Necromys lasiurus & & & & 1 \\
\hline Oligoryzomys sp. & & & 3 & \\
\hline \multicolumn{5}{|l|}{ Rodentia:Caviidae } \\
\hline Galea spixii & 1 & 1 & & \\
\hline \multicolumn{5}{|l|}{ Rodentia:Echmyidae } \\
\hline Thrichomys laurentius & 2 & & & \\
\hline \multicolumn{5}{|l|}{ Rodentia:Muridae } \\
\hline Rattus rattus & & 3 & & 6 \\
\hline Total per area & 10 & 8 & 20 & 7 \\
\hline Total per locality & & 18 & & 27 \\
\hline
\end{tabular}


are records considering the possible participation of marsupials in the reservoir system dating back to the first half of the $20^{\text {th }}$ century (Macchiavello 1943), yet has not received much attention. In Africa, non-rodent small mammals have been tested for $Y$. pestis in recent studies (Moore et al. 2015), with positive detection on individuals of Crocidura russula, a Soricomorph (Malek et al. 2014). The small mammals inhabiting the native vegetation remnants have also received little attention, as surveillance efforts are concentrated in areas where there is risk of human exposure (WHO 2005). The sylvatic small mammal assemblages are likely to play a role in the transmission cycles (Zeppelini et al. 2016), as the sylvatic fauna is the main origin of emergent and reemerging zoonosis (Plowright et al. 2017). In South America, where the reservoir systems are formed by a multitude of native and alien species (Schneider et al. 2014), investigating the sylvatic environments is fundamental to minimize possible biases created by a partially characterized small mammal community in order to avoid underestimating the array of withincommunity interactions that are able to affect the transmission cycle (Roche et al. 2013, Johnson et al. 2015). Due to its apparent diffuse spatial organization, surveying outside of areas within the rigid category of 'peridomestic environment' could explain phenomena such as the maintenance of bacterial circulation even during quiescence periods where the infection goes undetected in peridomestic/periurban surveillance. In reservoir systems that are less diverse and more spatially structured - usually dominated by one species like in Kazakhstan (Reijniers et al. 2012), and the United States (Richgels et al. 2016), the zoonotic cycles are more strongly tied to population parameters of the dominant host species (e.g. Davis et al. 2004, 2008, Reijniers et al. 2012) and to their discrete spatial distribution (Wilschut et al. 2013), making it easier to assess the limits of the cycle's geographic reach.
The circulation of $Y$. pestis presents long enzootic cycles where its activity is discrete (BenAri et al. 2012), often going undetected for several years, and misleading that the cycle is extinct. However, it is known that after long periods of epidemiological silence, there is the possibility of reemergence (Stenseth et al. 2008). As recently reported in foci in Africa (Malek et al. 2014), the region is currently responsible for over $90 \%$ of the cases registered every year (Raoult et al. 2013), and where several countries do not register any recent activity and are strong candidates for reemergence (Lotfy 2015).

The negative results for the detection tests performed in this study were expected. The last outbreak in Brazil occurred over 30 years ago (Almeida et al. 1989), the last human case was registered over a decade ago (Tavares et al. 2012), and the last large-scale investigation on the Northeastern foci registered only $0.25 \%$ prevalence (one individual of Monodelphis domestica out of 393 individuals trapped), and antibody low titer (Costa et al. 2017). Even during activity periods, the prevalence is historically very low $(0.1-4.5 \%)$ (Almeida et al. 1987, 1995). It is possible that the prevalence registered by the literature (PCP and research papers) in Brazil could be underrepresenting the real dimension of the infection, as it was focused on synanthropic rodents, and did not survey the fauna of the native vegetation fragments, possibly neglecting a fraction of the reservoir system (Zeppelini et al. 2016). It is also possible that the sampling of a species of small mammal ( $M$. demerarae) that has never been tested for $Y$. pestis could be seen as a sign of the latter. However, our current results do not allow us to further discuss the subject.

The absence of positive results indicate that the transmission cycle in the region is on quiescence, where it is undetectable (Haule et al. 2013). A recent study (Saavedra and Dias 2011) reported similar results for a survey performed on rodents, humans 
and carnivore sentinels. Historically, samples obtained from rodents test negative during periods where no human cases are detected (Almeida et al. 1988).

Currently, there has been substantial interest in studying ecology aspects of the transmission cycles, including the effects of climatic change (Davis et al. 2008, Keesing et al. 2010, Reijniers et al. 2012, 2014, Roche et al. 2013, Young et al. 2014, Moore et al. 2015, Mills et al. 2010, Rohr et al. 2011, Ben-Ari et al. 2012, Altizer et al. 2013). The general conclusions drawn from the literature available indicates an epidemiological transition period, where changes in climate, biodiversity and globalization can promote the emergence and reemergence of pathogens (Pongsiri et al. 2009). Although Plague has experienced a decrease in activity during the last century, it is still a present threat. Areas such as sub-Saharan Africa have been detecting activity in foci that were quiescent for decades (Malek et al. 2014, Lotfy 2015). The new cases detected in foci considered dormant for over 30 years has caused the WHO to classify Plague as a re-emerging disease (Richgels et al. 2016) and Brazilian foci are likely to resume activity as well (Zeppelini et al. 2016). This possibility reinforces the necessity of maintaining constant epidemiological surveillance.

\section{CONCLUSION}

The present investigation did not detect any activity of the Plague transmission cycle within the Paraíba Borborema Plateau focus. The small mammal reservoir system is clearly distinct between peridomestic and adjacent sylvatic ecotopes. The results indicate the occurrence of a quiescent period in the transmission cycle. However, this result does not discard the need for epidemiological surveillance due to the risk of rekindling foci after long dormant periods, especially given the current epidemiological transition occurring on a Global scale.

\section{ACKNOWLEDGMENTS}

Coordenação de Aperfeicoamento de Pessoal de Nível Superior (CAPES) and the Programa de PósGraduação em Ciências Biológicas - Zoologia (PPGCB) provided CGZ's masters' scholarship and research aid fund provided for the project. Thank you for the owners and staff of Engenho Bujari for the help and welcoming. Special thanks for Mr. João Carlos and Mrs. Conceição from FRP for all the support.

\section{REFERENCES}

ALMEIDA AMP, BRASIL DP, CARVALHO FG AND ALMEIDA CR. 1987. Pesquisa de Yersinia pestis em roedores e outros pequenos mamíferos nos focos pestosos do nordeste do Brasil no período de 1966 a 1982 . Rev Saude Publ 21: 265-267.

ALMEIDA AMP, BRASIL DP, LEAL NC, MELO MEB, RÊGO RVB AND ALMEIDA CR. 1989. Estudos bacteriológicos e sorológicos de um surto de peste no estado da Paraíba, Brasil. Mem Inst Oswaldo Cruz 84: 249-256.

ALMEIDA AMP, BRASIL DP, MELO MEB, LEAL NC AND ALMEIDA CR. 1988. Importância dos carnívoros domésticos cães e gatos na epidemiologia da peste nos focos do Nordeste do Brasil. Cad Saúde Pública, Rio de Janeiro 1: 49-55.

ALMEIDA AMP, LEAL NC, CARVALHO FG, SOBRINHO JD AND ALMEIDA CR. 1995. Plague surveillance in Brazil: 1983 - 1992. Rev Inst Med Trop São Paulo 37: 511-516.

ALMEIDA CR, ALMEIDA AR, VIEIRA JP, GUIDA U AND BUTLER T. 1981. Plague in Brazil during two years of bacteriological and serological surveillance. B World Health Organ 59: 591-597.

ALTIZER S, OSTFELD RS, JOHNSON PT, KUTZ S AND HARVELL CD. 2013. Climate change and infectious diseases: from evidence to a predictive framework. Science 341: 514-519.

ALVARES CA, STAPE JL, SENTELHAS PC, DE MORAES GJL AND SPAROVEK G. 2013. Köppen's climate classification map for Brazil. Meteorol Z 22: 711-728.

BEN-ARI T, NEERINCKX S, GAGE KL, KREPPEL K, LAUDISOIT A, LEIRS H AND STENSETH NC. 2012. Plague and Climate: Scales Matter. PLoS Pathog. 7: 1-6. 
BONVICINO CR, OLIVEIRA JA, CORDEIRO-ESTRELA P, D'ANDREA PS AND ALMEIDA AMP. 2015. A Taxonomic Update of Small Mammal Plague Reservoirs in South America. Vector Borne Zoonotic Dis 15: 571-579.

BUTLER T. 2013. Plague gives surprises in the first decade of the 21 st century in the United States and worldwide. Am J Trop Med Hyg 89: 788-793.

CHU MC. 2000. Laboratory Manual of Plague Diagnosis Tests. Geneva: World Health Organization, 129 p.

COSTA ECV, SOBREIRA M, LEAL NC AND ALMEIDA AMP. 2017. Rodents and other small mammal reservoirs in plague foci in northeastern Brazil. J Infec Dev Ctries 11: 426-430.

DAVIS S, BEGON M, BRUYN L, AGEYEV VS, KLASSOVSKIY NL, POLE SB, VILJUGREIN H, STENSETH NC AND LEIRS H. 2004. Predictive Thresholds for Plague in Kazakhstan. Science 304: 736738.

DAVIS S, TRAPMAN P, LEIRS H, BEGON M AND HEESTERBEEK JP. 2008. The abundance threshold for plague as a critical percolation phenomenon. Nature 454 : 634-637.

GAGE KLAND KOSOY MY. 2005. Natural history of plague: perspectives from more than a century of research. Annu Rev Entomol 50: 505-528.

HAULE M, LYAMUYA EE, HANG'OMBE BM, KILONZO BS AND MATEE MI. 2013. Investigation of fleas as vectors in the transmission of plague during a quiescent period in North-Eastern, Tanzania. J Entomol Nematol 5: 88-93.

HOLT AC, SALKELD DJ, FRITZ CL, TUCKER JR AND GONG P. 2009. Spatial analysis of plague in California: niche modeling predictions of the current distribution and potential response to climate change. Int $\mathrm{J}$ Health Geogr 8: $38-51$.

JOHNSON PT, DE ROODE JC AND FENTON A. 2015. Why infectious disease research needs community ecology. Science 349: 1259504.

KARIMI Y. 1978. Rapid laboratory diagnosis of plague. Bull Soc Pathol Exot Filiales 71: 45-48.

KEESING F ET AL. 2010. Impacts of biodiversity on the emergence and transmission of infectious diseases. Nature 468: 647-652.

LEAL NC AND ALMEIDA AMP. 1999. Diagnosis of plague and identification of virulence markers in Yersinia pestis by Multiplex-Pcr. Rev Inst Med Trop São Paulo 41: 339342.

LOTFY WM. 2015. Current perspectives on the spread of plague in Africa. Res Rep Trop Med 6: 21-30.

MACCHIAVELLO A. 1943. Epidemiology of Plague In Ecuador. Am J Publ Health 33: 807-811.
MALEK MA, HAMMANI A, BENELDJOUZI A AND BITAM I. 2014. Enzootic plague foci, Algeria. New Microbes New Infect 4: 13-16.

MILLS JN, GAGE KL AND KHAN AS. 2010. Potential Influence of Climate Change on Vector-Borne and Zoonotic Diseases: A Review and Proposed Research Plan. Environ Health Perspect 118: 1507-1514.

MINISTÉRIO DA SAÚDE. 2008. Manual de Vigilância e Controle da Peste. Brazil: Ministério da Saúde, 80 p.

MINISTÉRIO DAS MINAS E ENERGIA. 1981. Projeto RADAMBRASIL. Rio de Janeiro: Ministério das Minas e Energia, p. 744.

MOORE SM, MONAGHAN A, BORCHET JN, MPANGA JT, ATIKU LA, BOEGLER KA, MONTENIERI J, MACMILLAN K, GAGE KL AND EISEN RJ. 2015. Seasonal fluctuations of small mammal and flea communities in a Ugandan plague focus: evidence to implicate Arvicanthis niloticus and Crocidura spp. as key hosts in Yersinia pestis transmission. Parasit Vectors 8: $1-15$.

MORAIS NETO JM, HEGARTY KA, KARNER GD AND ALKMIM FF. 2009. Timing and mechanisms for the generation and modification of the anomalous topography of the Borborema Province, northeastern Brazil. Mar Pet Geol 26: 1070-1086.

PERRY RD AND FETHERSTON JD. 1997. Yersinia pestis etiologic agent of plague. Clin Microbiol Rev 10: 35-66.

PLOWRIGHT RK, PARRISH CR, MCCALLUM H, HUDSON PJ, KO AI, GRAHAM AL AND LLOYDSMITH JO. 2017. Pathways to zoonotic spillover. Nat Rev Microbiol 15(8): 502-510.

POLITZER R AND MEYER KF. 1965. Plague in the Americas. Scientific Publishing, Washington: Pan American Health Organization 115: 156.

PONGSIRI MJ, ROMAN J, EZENWA VO, GOLDBERG TL, KOREN HS, NEWBOLD SC, OSTFELD RS, PATTANAYAK SK AND SALKELD DJ. 2009. Biodiversity Loss Affects Global Disease Ecology. BioScience 59: 945-954.

PÔRTO KC, CABRAL JJP AND TABARELLI M. 2004. Brejos de Altitude em Pernambuco e Paraíba - História Natural, Ecologia e Conservação. Biodiversidade, Brazil: Ministério do Meio Ambiente 9: 324.

RAOULT D, MOUFFOK N, BITAM I, PIARROUX R AND DRANCOURT M. 2013. Plague: history and contemporary analysis. The J Infect 66: 18-26.

REIJNIERS J, BEGON M, AGEYEV VS AND LEIRS H. 2014. Plague epizootic cycles in Central Asia. Biol Lett 10: $1-4$.

REIJNIERS J, DAVIS S, BEGON M, HEESTERBEEK JAP, AGEYEV VS AND LEIRS H. 2012. A curve of thresholds governs plague epizootics in Central Asia. Ecol Lett 15: 554-560. 
RICHGELS KL, RUSSELL RE, BRON GM AND ROCKE TE. 2016. Evaluation of Yersinia pestis Transmission Pathways for Sylvatic Plague in Prairie Dog Populations in the Western U.S. Ecohealth 13: 415-427.

ROCHE B, ROHANI P, DOBSON AP AND GUEGAN JF. 2013. The impact of community organization on vectorborne pathogens. Am Nat 181: 1-11.

RODAL MJ, SALES MF, SILVA MJ AND SILVA AG. 2005. Flora de um Brejo de Altitude na escarpa oriental do planalto da Borborema, PE, Brasil. Acta Bot Bras 19: 843858.

ROHR JR, DOBSON AP, JOHNSON PT, KILPATRICK AM, PAULL SH, RAFFEL TR, RUIZ-MORENO D AND THOMAS MB. 2011. Frontiers in climate change-disease research. Trends Ecol Evol 26: 270-277.

SAAVEDRA RC AND DIAS JP. 2011. Infecção por Yersinia pestis no Estado da Bahia: controle efetivo ou silêncio epidemiológico? Rev Soc Bras Med Trop 44: 223-227.

SCHNEIDER MC, NAJERA P, ALDIGHIERI S, GALAN DI, BERTHERAT E, RUIZ A, DUMIT E, GABASTOU JM AND ESPINAL MA. 2014. Where does human plague still persist in Latin America? PLoS Negl Trop Dis 8: e2680.

STENSETH NC, ATSHABAR BB, BEGON M, BELMAIN SR, BERTHERAT E, CARNIEL E, GAGE KL, LEIRS H AND RAHALISON L. 2008. Plague: Past, Present, and Future. PLoS Med 5: 9-13.
TAVARES C, ARAGÃO AI, LEAL NC, LEAL-BALBINO TC, OLIVEIRA MBM, FERREIRA GMOG AND ALMEIDA AMP. 2012. Plague in Brazil: From Now and Then. In: Almeida AMP and Leal NC (Eds), Advances In Yersinia Research, New York: Springer, p. 69-77.

VIEIRA JBF, ALMEIDA AMP AND ALMEIDA CR. 1994. Epidemiologia e Controle da Peste no Brasil. Rev Soc Bras Med Trop 27: 51-58.

WHO - WORLD HEALTH ORGANIZATION. 2005. International Health Regulations. France: World Health Organization, $82 \mathrm{p}$.

WILSCHUT LI, ADDINK EA, HEESTERBEEK H, HEIER L, LAUDISOIT A, BEGON M, DAVIS S, DUBYANSKIY VM, BURDELOV LA AND DE JONG SM. 2013. Potential corridors and barriers for plague spread in central Asia. Int J Health Geog 12: 1-15.

YOUNG HS, DIRZO R, HELGEN KM, MCCAULEY DJ, BILLETER SA, KOSOY MY, OSIKOWICZ LM, SALKELD DJ, YOUNG TP AND DITTMAR K. 2014. Declines in large wildlife increase landscape-level prevalence of rodent-borne disease in Africa. Proc Natl Acad Sci U S A 111: 7036-7041.

ZEPPELINI CG, DE ALMEIDA AM AND CORDEIROESTRELA P. 2016. Zoonoses As Ecological Entities: A Case Review of Plague. PLoS Negl Trop Dis 10: e0004949. 